(c) The Author(s) 2016. This is an Open Access article, distributed under the terms of the Creative Commons Attribution licence (http://creativecommons. $\mathrm{org} /$ licenses/by/4.0/), which permits unrestricted re-use, distribution, and reproduction in any medium, provided the original work is properly cited.

\title{
Glacier change in the Karatal river basin, Zhetysu (Dzhungar) Alatau, Kazakhstan
}

\author{
Azamat KALDYBAYEV, ${ }^{1,2}$ Yaning CHEN, ${ }^{1}$ Evgeniy VILESOV ${ }^{3}$ \\ ${ }^{1}$ State Key Laboratory of Desert and Oasis Ecology, Xinjiang Institute of Ecology and Geography, \\ Chinese Academy of Sciences, Ürümqi, China \\ ${ }^{2}$ University of Chinese Academy of Sciences, Beijing, China \\ ${ }^{3}$ Faculty of Geography and Environmental Sciences, Al-Farabi Kazakh National University, Almaty, Kazakhstan \\ Correspondence: Yaning Chen <chenyn@ms.xjb.ac.cn>
}

\begin{abstract}
We investigated glacier changes in the Karatal river basin, the largest basin in Zhetysu (Dzhungar) Alatau, Kazakhstan, for the periods 1956-89, 1989-2001 and 2001-12, based on Landsat TM/ETM+ data analysis. In 1989, we found 243 glaciers with a total area of $142.8 \mathrm{~km}^{2}$; by 2012 these had shrunk to 214 glaciers with a total area of $109.3 \mathrm{~km}^{2}$, a decrease of $33.5 \mathrm{~km}^{2}$ over 23 years $\left(1.02 \% \mathrm{a}^{-1}\right)$. This very high shrinkage rate is likely connected with a general trend of increasing temperatures, and small glaciers being situated at the relatively low altitude of the outer Zhetysu Alatau ranges. We also analyzed the shrinkage rate of glaciers based on their differences in size, altitude and aspect of slopes, as well as other topographic parameters, in four sub-basins where glacier shrinkage varied between $18 \%$ and $39 \%$. Weather-station climate data showed a significant temperature increase and stable precipitation trends over the study period. We conclude that glacierized areas of the Karatal river basin are located in the most unfavorable conditions for glaciation, and as a result showed a higher shrinkage rate than other glacierized areas of the Tien Shan from 1956 to 2012.
\end{abstract}

KEYWORDS: climate change, glacier shrinkage, glacier mapping, mountain glaciers, remote sensing

\section{INTRODUCTION}

Glaciers play a crucial role in central Asia's hydrological cycle (Viviroli and others, 2003; Armstrong, 2010; Sorg and others, 2012). It has been demonstrated that even a basin whose glacier fraction is $<5 \%$ can provide a significant contribution from ice melt to summer runoff (Hagg and others, 2007), when water is most needed for irrigation (Sorg and others, 2012). While the seasonal snowpack stores water mainly on an intra-annual timescale, glaciers store water for decades and centuries, thus partly compensating interannual fluctuations of precipitation and snowmelt contribution to river runoff (Unger-Shayesteh and others, 2013).

The Karatal river basin, Zhetysu (Dzhungar) Alatau, Kazakhstan, is surrounded by arid lowlands and deserts (Fig. 1), where irrigation during vegetation growth periods often depends on glacier melt (Kaser and others, 2010). The runoff formed in this basin is used for hydropower generation at four hydroelectric power stations, and further downstream for irrigation in southeastern Kazakhstan.

In spite of the glaciers' importance for regional economies, regular glacier mass balance and other ground-based glaciological measurements were discontinued in the Karatal river basin, as well as in the entire Zhetysu Alatau mountains, after the collapse of the USSR during the 1990s. The first detailed glacier inventory, the 'Catalogue of Glaciers' (Katalog Lednikov SSSR, 1980), was published in 1980, and was based on airborne imagery from 1956. Cherkasov (2004) compiled the second glacier inventory, using topographic maps on a 1:25000 scale, based on aerial photographs taken in 1972, and two more limited glacier studies were conducted for the 1990s and 2000s. These inventories, however, remained as unpublished reports (Vilesov and others, 2013). Nevertheless, analyses of glacier changes for the entire Zhetysu Alatau were reported by several authors, who estimated the total decrease of the glacier area in the Karatal river basin was 34.8\% during 1956-2000 (Severskiy and others, 2012; Vilesov and others, 2013). Thus, changes in glacier surface area in Zhetysu Alatau, including Karatal basin glaciers, are still poorly understood. This paper presents our detailed analyses of the glacier areas of the Karatal river basin for the periods 1956-89, 1989-2001 and 2001-12, using wellestablished semi-automatic methods based on band ratio techniques (Paul and others, 2013).

\section{STUDY AREA}

The Karatal river basin, the largest basin in Zhetysu Alatau, covers an area of $19100 \mathrm{~km}^{2}$; the total area of the four subbasins studied here is $4370 \mathrm{~km}^{2}$ (Kudekov, 2002). The Karatal river originates on the northwestern slopes of the Zhetysu Alatau central ridge. It is formed by the confluence of the Kora, Chizhin and Tekeli rivers (Vilesov and others, 2013), while further on the plain it meets with its largest tributary, the Koksu river (Katalog Lednikov SSSR, 1980).

The Karatal river basin is located in the outer western Zhetysu Alatau, where the elevations of the highest mountain crests range between 3800 and 3850 ma.s.l. (Katalog Lednikov SSSR, 1980). Most glaciers found here are small $\left(<1 \mathrm{~km}^{2}\right)$ (Vilesov and others, 2013).

The climate of Zhetysu Alatau is formed by air masses from arctic and temperate areas. Arctic air masses flow from the north and northwest during winter, reducing air temperature in this region (Vilesov and others, 2013). Temperate air masses are formed over western Siberia, Kazakhstan and the Turanian plateau, as well as over the 


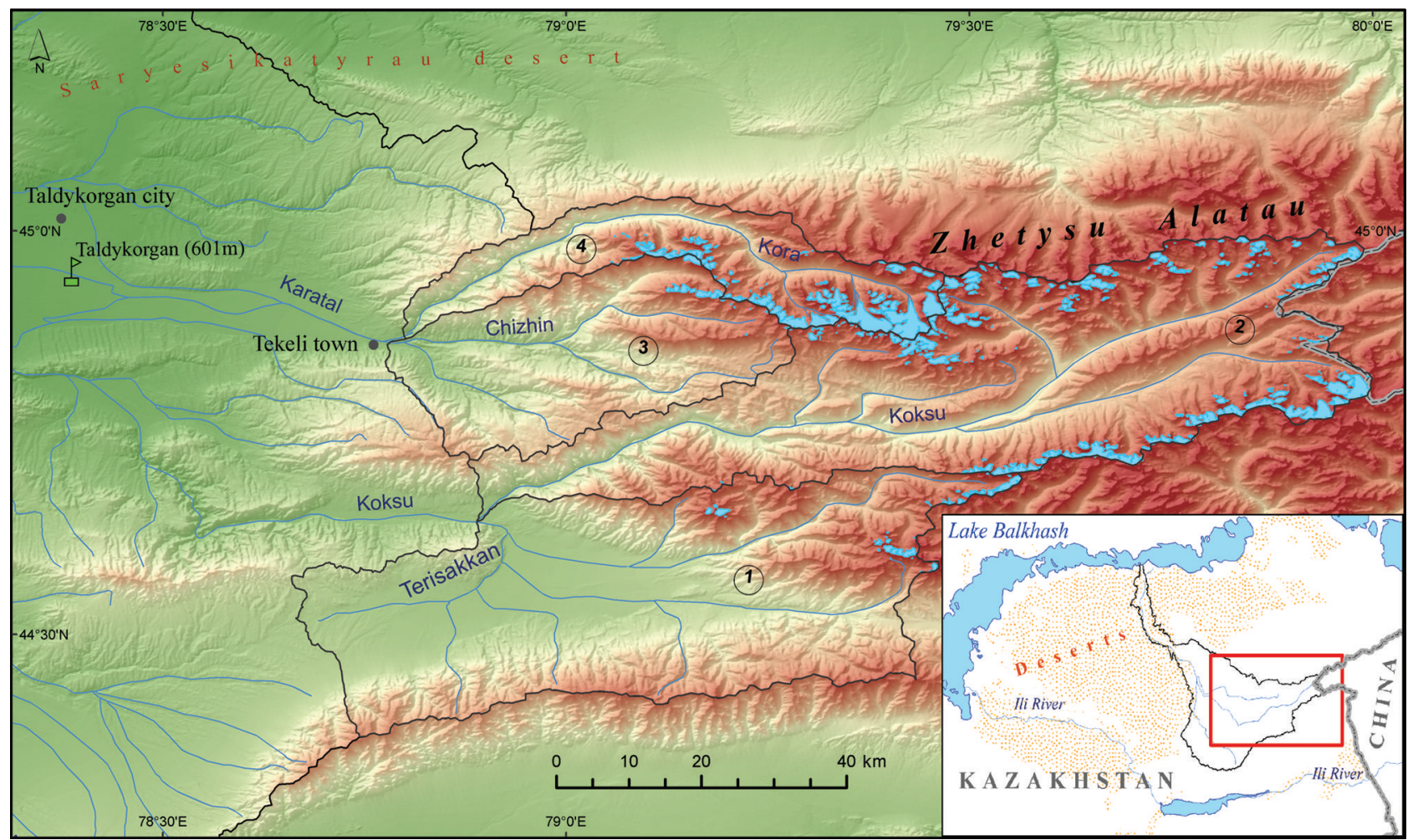

Fig. 1. Location of the study area. Map based on Shuttle Radar Topography Mission 3 (SRTM3) DEM. Sub-basins: 1. Terisakkan; 2. Koksu; 3. Chizhin; 4. Kora.

Atlantic Ocean, which has the greatest impact on the Zhetysu Alatau climate during the entire year. Hot air masses are formed over the intensely heated Turanian plateau; however, their incursions into the region during summer are very rare.

The mean annual air temperature is -5 to $-7^{\circ} \mathrm{C}$ in the high-altitude zone of Zhetysu Alatau; January is the coldest month, at -13 to $-14^{\circ} \mathrm{C}$. The spatial distribution of precipitation is controlled by altitude and varies from 1000 to $1600 \mathrm{~mm} \mathrm{a}^{-1}$, with maximum amounts occurring at 1800 2200 m a.s.I. (Katalog Lednikov SSSR, 1980).

\section{DATA AND METHODS}

All of the selected Landsat Thematic Mapper (TM) and Enhanced TM Plus (ETM+) images were in good condition, and almost free of clouds and snow (Table 1). Nevertheless, several scenes for each year were also used due to different snow conditions and data gaps. Images provided by the US Geological Survey were processed to Standard Terrain Correction (Level 1T), achieving systematic radiometric and geometric accuracy. Landsat TM and ETM+ scenes were co-registered to the 2001 Landsat ETM+ scene, and root-mean-square error (RMSE) was within \pm 0.5 pixel.

Thresholding of ratio images is an efficient and timeeffective approach compared to manual digitization, although the latter enables identification of snow and ice in shadows (Paul and others, 2003; Paul and Kääb, 2005; Bolch and Kamp, 2006). The advantages of thresholding are that it is simple to apply and the results are highly accurate for debris-free ice (Albert, 2002; Andreassen and others, 2008; Paul and Andreassen, 2009). Paul and others (2013) found an overall good agreement for clean ice, with sufficient contrast with the surrounding terrain (differences 5\%). Based on these results, they concluded that automated mapping of clean ice is preferable to manual digitization and recommended using

Table 1. Satellite imagery used in this study

\begin{tabular}{|c|c|c|c|c|c|}
\hline Date & Satellite and sensor & Path/row & $\begin{array}{l}\text { Spatial resolution } \\
\qquad \mathrm{m}\end{array}$ & Suitability of scenes & Utilization \\
\hline 14 Sept 1989 & Landsat TM & $147 / 29$ & $30 / 120$ & $\begin{array}{l}\text { Some seasonal snow on } \\
\text { the southeast part }\end{array}$ & Main source \\
\hline 9 Sept 1990 & Landsat TM & $148 / 29$ & $30 / 120$ & & Additional information \\
\hline 4 Sept 2000 & Landsat ETM+ & $148 / 29$ & $15 / 30 / 60$ & Some seasonal snow & Additional information \\
\hline 22 July 2001 & Landsat ETM+ & $148 / 29$ & $15 / 30 / 60$ & & Main source \\
\hline 25 July 2002 & Landsat ETM+ & $148 / 29$ & $15 / 30 / 60$ & Some seasonal snow & Additional information \\
\hline 11 Sept 2011 & Landsat TM & $148 / 29$ & $30 / 120$ & & Additional information \\
\hline 20 July 2012 & Landsat ETM+ & $148 / 29$ & $15 / 30 / 60$ & Scan-line corrector off & Main source \\
\hline
\end{tabular}




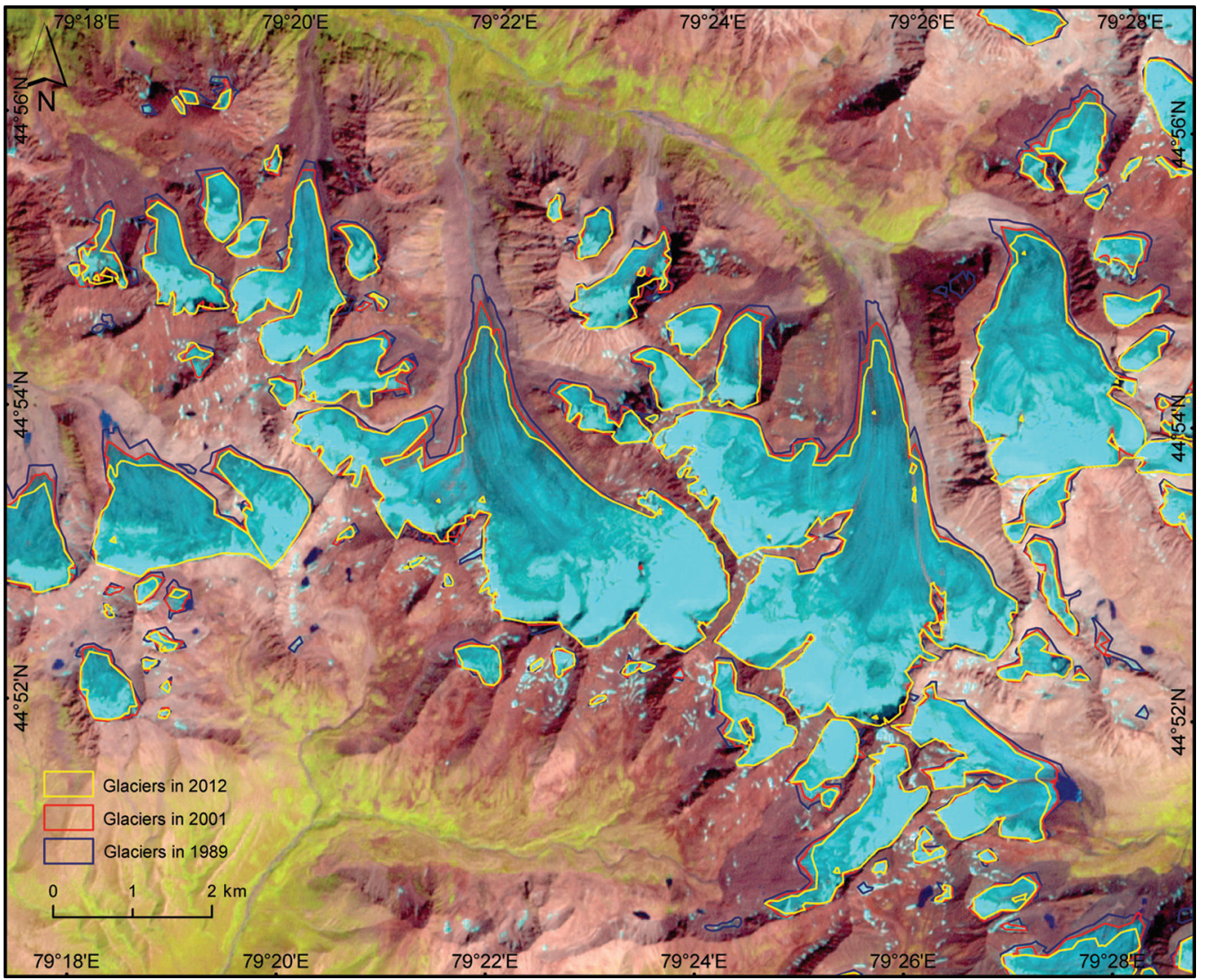

Fig. 2. Example of glacier changes in part of Kora sub-basin from 1989 to 2012. Background based on pansharpened Landsat ETM+ (22 August 2001).

the latter method only for required corrections of incorrectly mapped glacier parts (e.g. debris cover, shadows).

We applied a well-established semi-automated approach using the TM3/TM5 band ratio to produce glacier outlines. Misclassified areas (e.g. snowpatches, cast shadows and lakes) were corrected manually using false-color composite (TM bands 5, 4 and 3) on the Landsat imagery (Fig. 2). All of the images were obtained for cloud-free conditions and for the ablation period when the extent of snow cover was minimal, to reduce potential uncertainty in glacier boundary delineation. Changes in the extent of glaciers were assessed with regard to images from 1989, 2001 and 2012, and analyzed according to the surface area, aspect and elevation of glaciers.

Supraglacial debris cover is a factor reducing the accuracy of the glacier outline. However, in our study area, the glaciers were almost free of debris cover. Repeated mapping of glacier samples with different surface areas using different types of imagery has shown that the error in estimation of individual glacier area is $<5 \%$ (Kutuzov and Shahgedanova, 2009). An assessment by Paul and others (2003) shows that this accuracy allows one to achieve an error of $<3 \%$ for large $(>100)$ samples of glaciers. We used the glacier area from the 1989 image as a mask to minimize misclassification due to certain factors (e.g. seasonal snow cover). When using this mask, we assumed that glaciers did not advance between 1989 and 2012. The mask also maintained consistency in the location of the upper glacier boundary and the margins of nunataks. This consistency is important in the case of seasonal snow that hampers correct identification of the upper glacier boundary (Bolch and others, 2010). We mapped only glaciers that were
$>0.01 \mathrm{~km}^{2}$, as a smaller threshold would include many features that were likely to be snowpatches. Where a glacier had split into several fragments, the net area change in a studied period was based on the total area of the individual fragments. The characteristic parameters (e.g. hypsography, median elevation and aspect) were calculated for each glacier for 1989, 2001 and 2012 based on the Advanced Spaceborne Thermal Emission and Reflection Radiometer (ASTER) Global Digital Elevation Model (GDEM) version 2. The DEM used matched the glacier outlines well. No DEM representing the 1989 conditions was available.

We estimated the uncertainty by the buffer method suggested by Granshaw and Fountain (2006) and Bolch and others (2010). The buffer size was chosen to be half of the estimated RMSE, i.e. $7.5 \mathrm{~m}$ to each side. The resulting accuracy was within $\pm 5 \%$.

For more detailed analyses of the glacier changes, we subdivided the Karatal river basin into four sub-basins (Terisakkan, Koksu, Chizhin and Kora) according to landscape differences. Results of glacier areas obtained for each sub-basin were compared with the same glacierized areas defined in the first glacier inventory for 1956. Information about the glacier characteristics from the first glacier inventory was available only as tables and schematic maps. Glaciers smaller than $0.1 \mathrm{~km}^{2}$ were treated as bulk samples in the Catalogue of Glaciers, without information about their locations. We did not include these small glaciers in our calculation of the total glacierized area and showed them separately for all study regions.

In order to obtain information about climate trends for the Karatal river basin, we acquired data from Taldykorgan, the nearest available weather station to our study area. This 


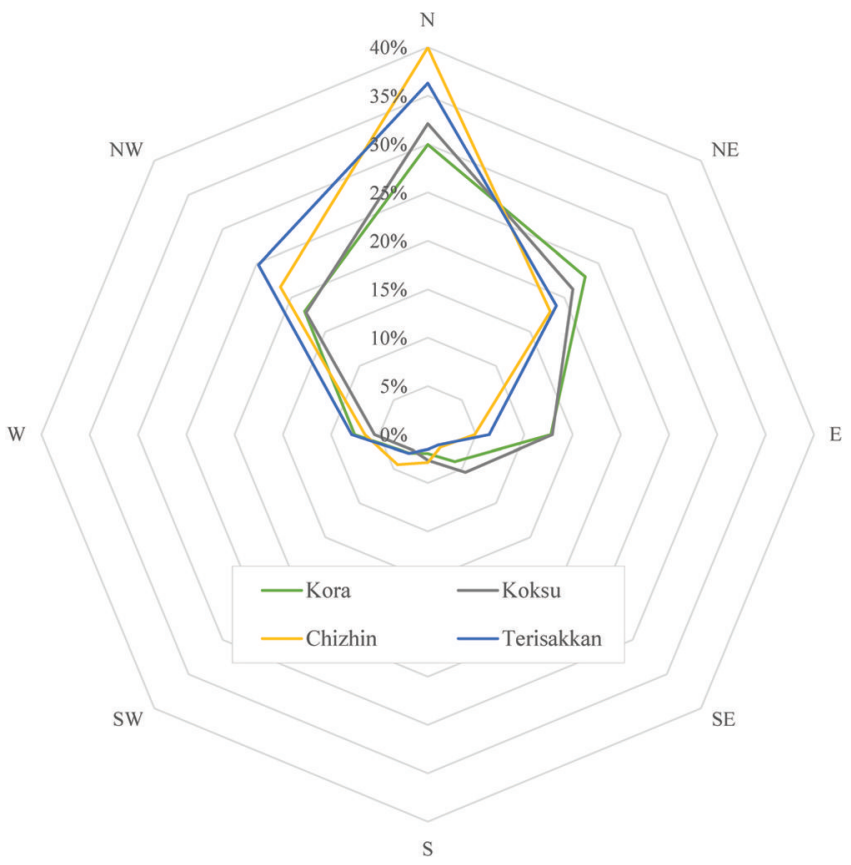

Fig. 3. Distribution of glacier areas according to aspect in different sub-basins during 1989-2012.

station is situated in the foothills ( $\sim 600$ ma.s.l.) and has provided long-term temperature and precipitation records since 1960.

\section{RESULTS}

\subsection{Glacier characteristics}

We identified and mapped 214 glaciers, with a total area of $109.3 \mathrm{~km}^{2}$, in 2012 . The vast majority $(91 \%)$ were small glaciers $\left(<1 \mathrm{~km}^{2}\right)$, which covered more than half of the total glacierized area. There were only four large glaciers, between 4 and $10 \mathrm{~km}^{2}$ in size, but these contributed $23.5 \%$ of the total glacierized area in the study region.

The distribution of glacier aspect was determined using ASTER GDEM v2 and exhibited small differences between the regions. Most of the glaciers were north-facing (north, northwest and northeast) (Fig. 3) and situated between 3000 and $4000 \mathrm{~m}$ a.s.l. (Fig. 4). The largest area of glaciers was located between 3400 and 3600 ma.s.l., and the majority were concentrated in the Kora and Koksu sub-basins.

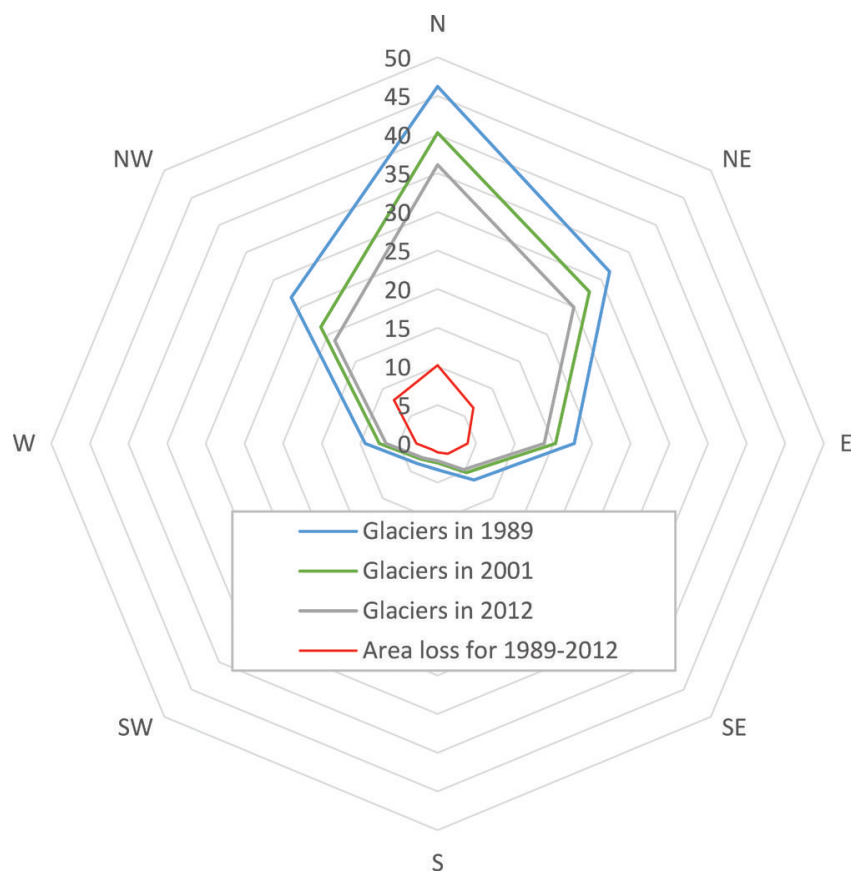

Fig. 4. Distribution of glacier areas and their changes according to aspect in the Karatal river basin during 1989-2012.

The median elevation of the glaciers, which is a suitable and widely used indicator of the long-term equilibrium-line altitude (ELA) based on topographic data (Braithwaite and Raper, 2010), is situated at $\sim 3460 \mathrm{~m}$ a.s.l. Glaciers at lower elevations were located mostly in the northwestern corner of the study area (the Kora sub-basin), whereas glaciers at the highest elevations were situated in the southeastern part.

\subsection{Glacier changes}

We identified 243 glaciers in 1989, 226 in 2001 and 214 in 2012 which were listed in the Catalogue of Glaciers with total areas of $142.8,122.2$ and $109.3 \mathrm{~km}^{2}$, respectively (Table 2). Thus, the summarized area change for the period 1956-89, based on our defined mountain regions, was $-28 \%$. Area change for $1989-2001$ was $-14 \%$, and area change for $2001-12$ was $-11 \%$; for the whole period, the total glacierized area decreased from $199.2 \mathrm{~km}^{2}$ (285 glaciers) in 1956 , to $109.3 \mathrm{~km}^{2}$ (214 glaciers) in 2012, a shrinkage of $45 \%$ in 56 years. During our study period, 71 glaciers listed in the Catalogue of Glaciers and 39 unlisted small glaciers were not found. All of the glaciers

Table 2. Changes in glacier number and area

\begin{tabular}{|c|c|c|c|c|c|c|c|c|c|c|}
\hline \multirow[t]{3}{*}{ Region } & \multicolumn{4}{|c|}{ Glacier area (number) } & \multicolumn{5}{|c|}{ Area change (annual rate) } & \multirow{2}{*}{$\begin{array}{c}\text { Mean size } \\
\text { in } 1989\end{array}$} \\
\hline & 1956 & 1989 & 2001 & 2012 & 1956-89 & 1989-2001 & 2001-12 & 1956-2012 & 1989-2012 & \\
\hline & $\mathrm{km}^{2}$ & $\mathrm{~km}^{2}$ & $\mathrm{~km}^{2}$ & $\mathrm{~km}^{2}$ & $\%$ & $\%$ & $\%$ & $\%$ & $\%$ & $\mathrm{~km}^{2}$ \\
\hline Terisakkan & $14.1(36)$ & $8.4(21)$ & $6.5(21)$ & $5.1(17)$ & $-40(-1.22)$ & $-23(-1.96)$ & $-20(-1.8)$ & $-63(-1.13)$ & $-39(-1.68)$ & 0.403 \\
\hline Koksu & $108.6(167)$ & 75.3 (149) & $64.1(140)$ & $56.1(135)$ & $-31(-0.93)$ & $-15(-1.24)$ & $-13(-1.14)$ & $-48(-0.86)$ & $-26(-1.11)$ & 0.506 \\
\hline Chizhin & $8.7(19)$ & $4.9(11)$ & $4.2(10)$ & $3.8(10)$ & $-44(-1.32)$ & $-15(-1.24)$ & $-9(-0.79)$ & $-56(-1.0)$ & $-22(-0.97)$ & 0.445 \\
\hline Kora & $67.8(66)$ & $54.1(62)$ & $47.5(55)$ & $44.2(52)$ & $-28(-0.61)$ & $-14(-1.03)$ & $-7(-0.63)$ & $-35(-0.62)$ & $-18(-0.80)$ & 0.873 \\
\hline Total & $199.2(285)$ & $142.8(243)$ & $122.2(226)$ & $109.3(214)$ & $-28(-0.86)$ & $-14(-1.20)$ & $-11(-0.96)$ & $-45(-0.81)$ & $-23(-1.02)$ & 0.588 \\
\hline $\begin{array}{l}\text { Glaciers }<0.1 \mathrm{~km}^{2} \\
\text { in } 1956\end{array}$ & $3.6(73)$ & $2.36(77)$ & $0.76(39)$ & $0.59(34)$ & $-34(-1.04)$ & $-68(-5.63)$ & $-22(-1.99)$ & $-83(-1.49)$ & $-75(-3.25)$ & 0.031 \\
\hline
\end{tabular}




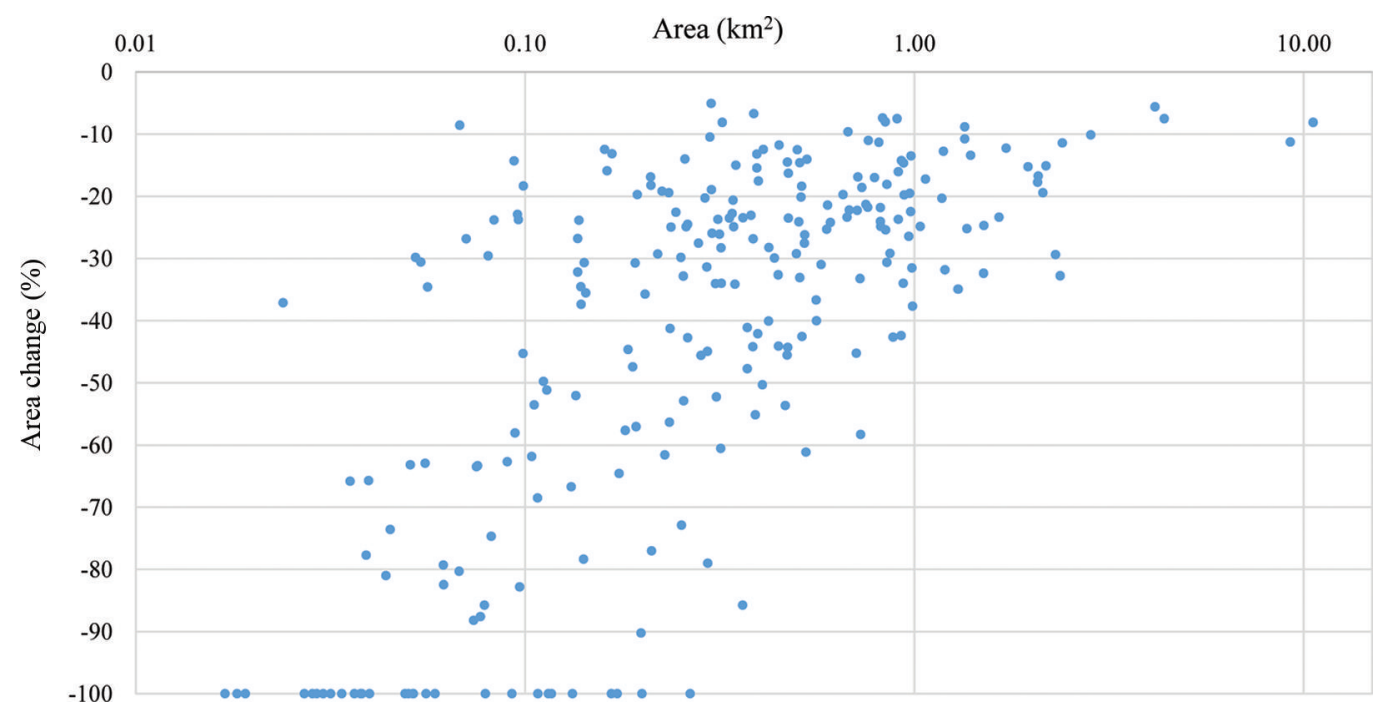

Fig. 5. Scatter plot of relative changes in glacier area vs initial glacier size for the 243 glaciers during 1989-2012.

shrank continuously throughout the study period. Our results indicate that glacier area loss in the Karatal river basin was $23 \%\left(1.02 \% \mathrm{a}^{-1}\right)$ for $1989-2012$. The Kora subbasin had the largest glaciers, with a mean size of $0.873 \mathrm{~km}^{2}$, while the Terisakkan sub-basin had the smallest, with a mean size of $0.403 \mathrm{~km}^{2}$. Terisakkan had the highest shrinkage rate, $39 \%$ from 1989 to 2012 . The rate of decrease in glacier numbers was significantly higher (more than $40 \%$ ) for the Terisakkan and Chizhin glacierized areas during the study period.

Analysis of the relative area change against the initial glacier area indicates a greater relative loss for smaller glaciers (Fig. 5). However, there was a large scatter of loss, especially for smaller glaciers, while in all size classes there were glaciers that had shrunk only slightly. Absolute area loss was higher for larger glaciers (Fig. 6), and glacier median elevation increased by $40 \mathrm{~m}$, while the average minimum elevation of the glaciers rose $\sim 47 \mathrm{~m}$, from 3288 up to 3335 m a.s.l., for 1989-2012.

All elevations showed a reduction in glacier area during 1989-2012 (Fig. 7). The glaciers of the west and northwest aspects decreased by up to $30 \%$, while northern and northeastern aspects decreased by only $\sim 20 \%$.

\section{DISCUSSION}

The area changes of the investigated glaciers confirmed an expected and widely published trend of glacier shrinkage (Sorg and others, 2012; Unger-Shayesteh and others, 2013). However, with a shrinkage rate of about $0.8-1 \% \mathrm{a}^{-1}$ for the periods 1956-89 and 1989-2012, our results for the Karatal river basin study area showed a comparatively higher shrinkage rate than some other glacierized areas of the Tien Shan (Aizen and others, 2007; Bolch, 2007; Kutuzov and Shahgedanova, 2009; Kriegel and others, 2013). Results of previous studies showed large variations in different parts of the Tien Shan: $-0.76 \% \mathrm{a}^{-1}$ (mid-1970s to mid-2000s; Kriegel and others, 2013) in the western Tien Shan; $-0.38 \% \mathrm{a}^{-1}$ (1963-2003; Aizen and others, 2006) and $-0.76 \% \mathrm{a}^{-1}$ (1963-2000; Niederer and others, 2008) in the northern Tien Shan; $-0.11 \% \mathrm{a}^{-1}$ (1975-2008; Pieczonka and Bolch, 2015) in the central Tien Shan; and $-0.35 \% \mathrm{a}^{-1}$ (1963-2000; $\mathrm{Li}$ and others, 2007) in the eastern Tien Shan. This intensive decrease of glacier area is consistent with earlier studies which showed that the highest glacier shrinkage occurred in the outer ranges of the Tien Shan and the peripheral, lowerelevation ranges near the densely populated forelands; significantly smaller rates were reported for glaciers in inner

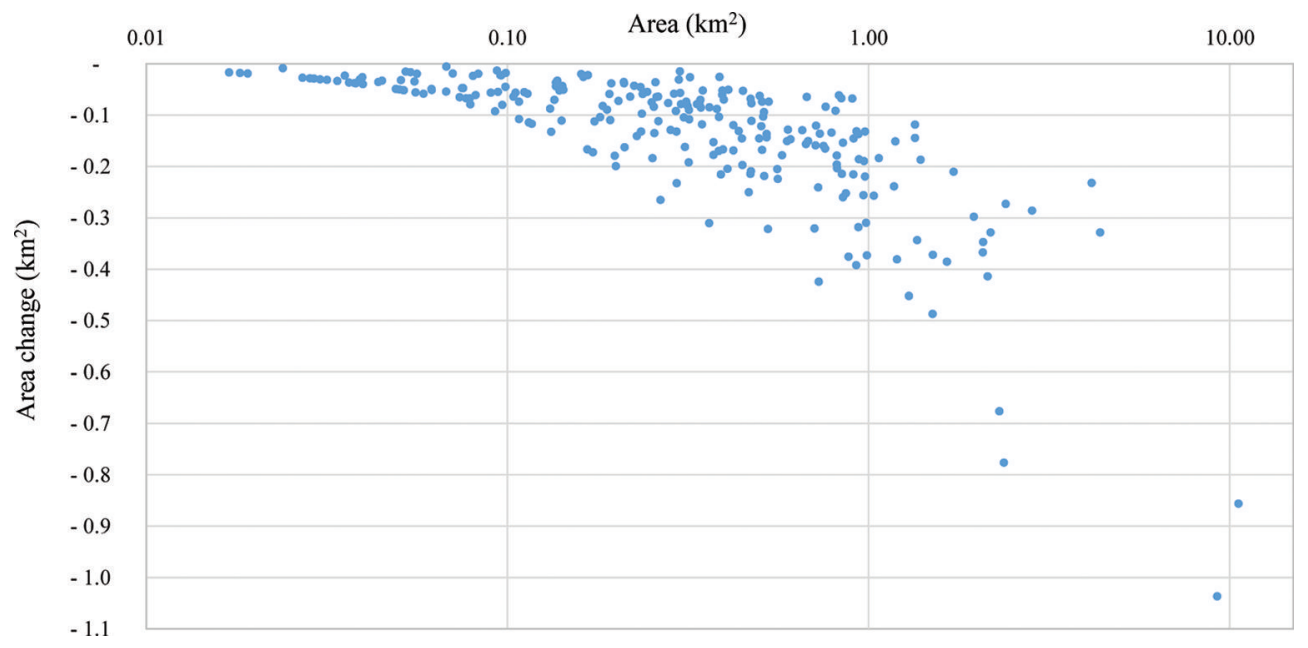

Fig. 6. Scatter plot of absolute changes in glacier area vs initial glacier size during 1989-2012. 


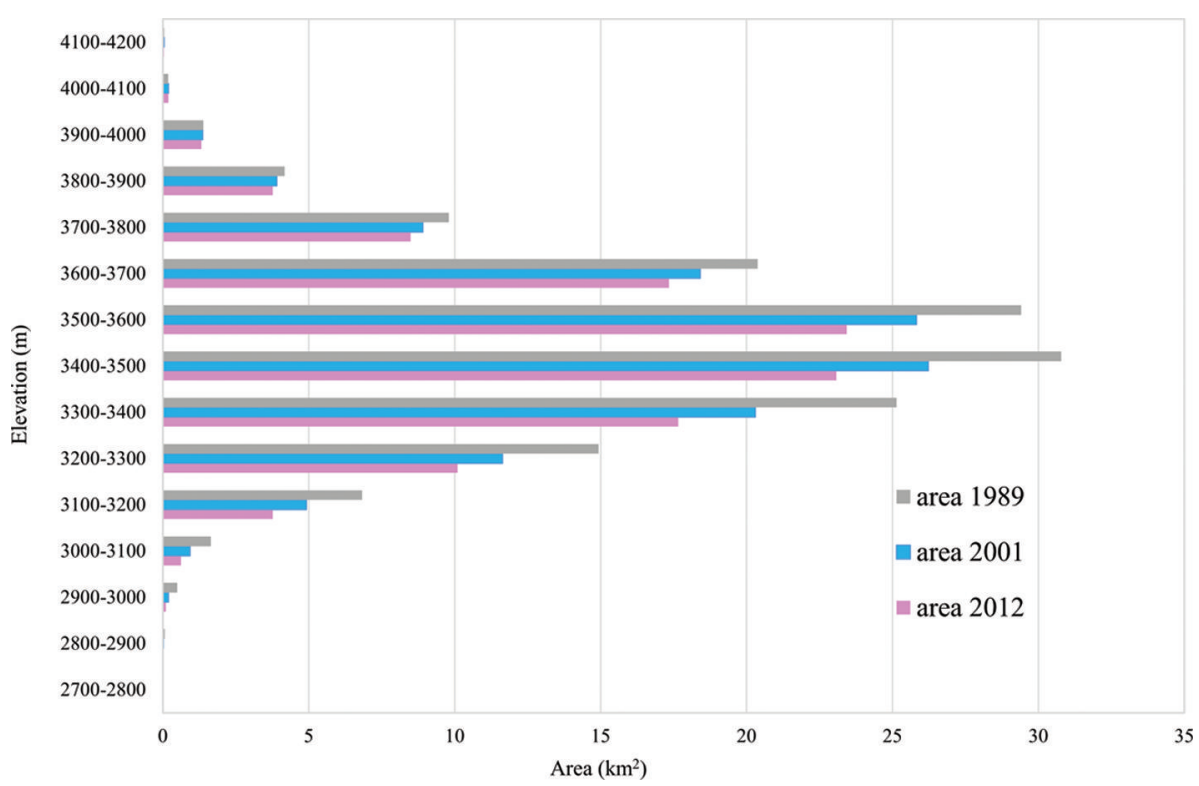

Fig. 7. Distribution of glacier areas and their changes vs elevation interval in the Karatal river basin.

ranges (Narama and others, 2010; Sorg and others, 2012). The assessments by Aizen and others (2006) for 1977-2003 in the inner region of the Tien Shan, and Narama and others (2006) for 1971-2002 in the western Tien Shan, indicated a glacial area loss of $8-9 \%\left(0.26-0.29 \% \mathrm{a}^{-1}\right)$, while glaciers in the peripheral regions of the northern Tien Shan shrank considerably faster. For instance, for Zailiyskiy and Kungey Alatau, Bolch (2007) found a shrinkage rate of $0.73 \% \mathrm{a}^{-1}$ for 1955-99. Kokarev and Shesterova (2014) studied glacier areas in the southern part of Zhetysu Alatau in a region close to our study area, and the shrinkage rate was also quite high, at $\sim 0.86 \% \mathrm{a}^{-1}$. Hagg and others (2012) mapped glaciers in the Big Naryn basin during 2007. By comparing their results with the 1955 Soviet glacier inventory, they reported that the rate of decrease varied from 0.27 to $0.81 \% \mathrm{a}^{-1}$ between mountain ranges, showing an increasing shrinkage rate from the inner to outer parts. Glaciers in the outer ranges of the Tien Shan which receive the highest precipitation volumes are particularly sensitive to climatic change due to their large mass-turnover rates (Narama and others, 2010).

Regions with mostly small glaciers are generally more sensitive to change because smaller glaciers have a shorter response time to climate change (Bahr and others, 1998; Ye and others, 2001). It is also reported that smaller glaciers, with a greater area-to-margin-length ratio, shrink faster than larger glaciers under the same ablation rate (Granshaw and Fountain, 2006). In the Karatal river basin, the vast majority of glaciers are small, with sizes $<1 \mathrm{~km}^{2}$. These glaciers cover more than half of the total area, as is common in mountains of the mid-latitudes. Our results indicate that the mean size of the glacier area in the Karatal river basin was $0.588 \mathrm{~km}^{2}$. The difference in the shrinkage rates of glacier areas among the sub-basins in our study area can be explained by the difference in mean size and aspect. For example, Terisakkan had the highest shrinkage rate, reaching 39\% from 1989 to 2012. The mean glacier size in Terisakkan was almost twice as small as that in the Kora sub-basin, where the shrinkage rate for the same period was $18 \%$.

Although climate warming has been the main cause of glacier change during the past 56 years, the topographic factor also plays an important role. An additional reason for greater area loss may be the lower elevation of glaciers in the Karatal basin compared to other parts of the Tien Shan. An increase in local mean air temperature, with no change in precipitation, will cause an upward shift of the ELA by $\sim 150 \mathrm{~m}$ for each ${ }^{\circ} \mathrm{C}$ of atmospheric warming (Stocker and others 2013). At lower elevations, such an upward shift of the ELA heightens the risk of the entire area of glaciers falling into the ablation zone.

All elevations showed a reduction in glacier area during 1989-2012, but the largest area changes occurred on the western and northwestern aspects. South-facing glaciers were not widespread in the study area, but individual glaciers showed a remarkable reduction in glacier area. This may be due to greater incoming solar radiation, especially on the southern aspects, because of the general trend of increasing temperatures after the late 1970s (e.g. Evans, 2006; Li and others, 2011). Moreover, most ranges of the Zhetysu Alatau, which are oriented to the west, are also under the influence of summer warm westerlies that originate over the deserts located to the south of Lake Balkhash (Aizen and others, 1997; Vandenberghe and others, 2006). Furthermore, the westerlies are long-distance carriers of fine-grained loess from the deserts of central Asia to the Tien Shan (Vandenberghe and others, 2006; Issanova and others, 2013), which pollutes glacial surfaces, intensifying the melting rate ( $\mathrm{Li}$ and others, 2011). In particular, glaciers located on the western slopes that face strong winds and dust storms from the desert could experience intense contamination. The frequency of dust storms directed to part of the Zhetysu range has increased during the past few decades (Issanova and others, 2013), causing the shrinkage rate of our study area, located in the western Zhetysu Alatau, to be almost three times more severe $\left(0.86 \% \mathrm{a}^{-1}\right)$ than for the Bortala river in the eastern Zhetysu Alatau $\left(0.32 \% \mathrm{a}^{-1}\right)$ (Wang and others, 2014).

The Catalogue of Glaciers listed 285 glaciers, as well as 73 glaciers smaller than $0.1 \mathrm{~km}^{2}$ which were treated as bulk samples with no information about their locations. We identified 214 glaciers, 34 of which were not listed in the Catalogue of Glaciers, suggesting that these unlisted glaciers are remnants of those glaciers that were already $<0.1 \mathrm{~km}^{2}$ by 


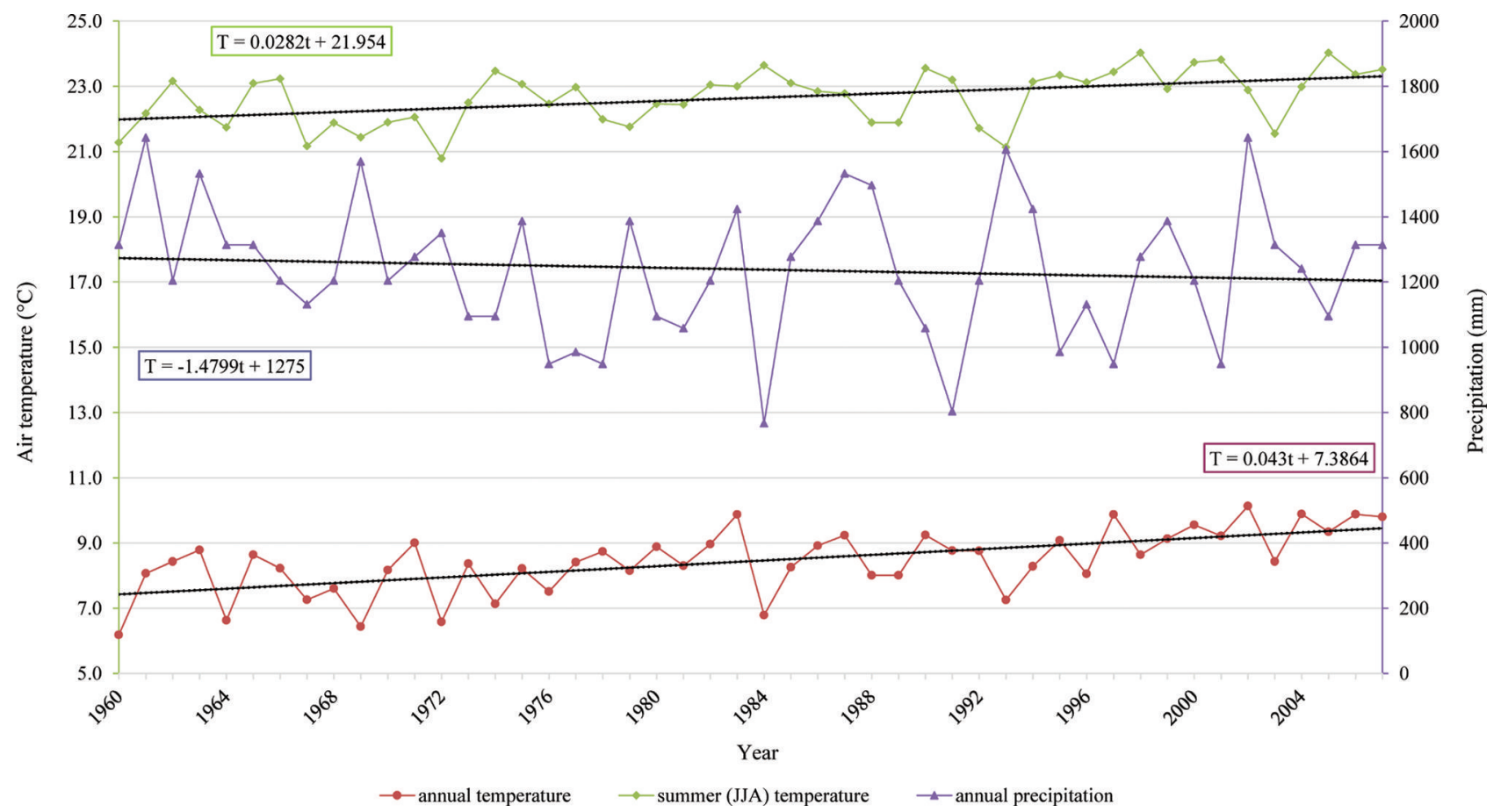

Fig. 8. Annual and summer (June-August (JJA)) temperature and annual precipitation at Taldykorgan station.

the mid-20th century. The remaining 71 glaciers that were listed and 39 smaller glaciers could not be found. Several studies (Bolch and Marchenko, 2009; Shahgedanova and others, 2010) have found differences of $\sim 5 \%$ between their results and the Catalogue of Glaciers.

Annual mean temperature and total precipitation over the 47 year period 1960-2007 were analyzed from Taldykorgan weather station, situated near the study area. The linear trend analysis of mean temperature indicated that the average rate of temperature increase was $0.43^{\circ} \mathrm{C}(10 \mathrm{a})^{-1}$, while the summer (June-August) temperature rose $0.28^{\circ} \mathrm{C}(10 \mathrm{a})^{-1}$ (Fig. 8). From 1960 to 2007 , records at the same station displayed a slight decrease in annual precipitation. Increasing temperature leads to (1) increasing energy available for ice- and snowmelt; (2) decreasing snow accumulation; and (3) lower albedo of the glacier surface (Ageta and Kadota, 1992; Fujita and Ageta, 2000; Wang and others, 2014). The temperature increase caused the rainfall rate to increase, rather than snowfall in the high-altitude glacierized areas, leading to reduced accumulation and accelerated ablation, especially during summer (Chaulagai, 2003). Between 1960 and 2007, two climatic factors, increased temperature and slightly decreased precipitation, led to significant glacier area loss.

\section{SUMMARY}

This study demonstrates the scientific value of detailed multitemporal remote-sensing analyses of glacier changes for the Karatal river basin, which currently lacks sufficient records of observational data. In the basin, we identified 243 glaciers with a total area of $142.8 \mathrm{~km}^{2}$ in 1989 that had decreased to $109.3 \mathrm{~km}^{2}$ by 2012 , a loss of $33.5 \mathrm{~km}^{2}$ (shrinkage rate $1.02 \% \mathrm{a}^{-1}$ ). Our results show higher shrinkage rates for the study area than some other glacierized areas of the Tien Shan. This phenomenon is likely connected not only to the location of our study area in the periphery of the Zhetysu Alatau, which had less favorable climatic conditions than the inner ranges, but also to smaller glacier sizes with a complete absence of debris cover. The differences in glacier area shrinkage among the sub-basins can be explained by variations in sizes, orientations and local climate conditions. No glaciers advanced during the investigation period. Clearly, complex glacier-climate interactions need to be further investigated.

\section{ACKNOWLEDGEMENTS}

The research is supported by the Program of the State Key Laboratory of Desert and Oasis Ecology, Xinjiang Institute of Ecology and Geography, Chinese Academy of Sciences (Y371163), and the National Natural Science Foundation of China (41471030). We thank V. Aizen, an anonymous reviewer and the chief editor J. Graham Cogley, for thorough reviews and valuable comments which significantly improved the paper. We are grateful to Patricia Johnston for her useful remarks and constant help in English editing of the manuscript.

\section{REFERENCES}

Ageta Y and Kadota T (1992) Predictions of changes of glacier mass balance in the Nepal Himalaya and Tibetan Plateau: a case study of air temperature increase for three glaciers. Ann. Glaciol, 16, 89-94

Aizen V, Aizen E, Melack J and Martma T (1997) Isotopic measurements of precipitation on central Asian glaciers (Southeastern Tibet, northern Himalayas, central Tien Shan). J. Geophys. Res., 101(4), 9185-9198

Aizen VB, Kuzmichenok VA, Surazakov AB and Aizen EM (2006) Glacier changes in the central and northern Tien Shan during the last 140 years based on surface and remote-sensing data. Ann. Glaciol., 43, 202-213

Aizen VB, Kuzmichenok, VA, Surazakov $A B$ and Aizen EM (2007) Glacier changes in the Tien Shan as determined from 
topographic and remotely sensed data. Global Planet. Change, 56, 328-340

Albert TH (2002) Evaluation of remote sensing techniques for ice area classification applied to the tropical Quelccaya ice cap. Peru. Polar Geogr., 26(3), 210-226

Andreassen LM, Paul F, Kääb A and Hausberg JE (2008) Landsatderived glacier inventory for Jotunheimen, Norway, and deduced glacier changes since the 1930s. Cryosphere, 2(2), 131-145

Armstrong RL (2010) The glaciers of the Hindu Kush-Himalayan region: a summary of the science regarding glacier melt/retreat in the Himalayan, Hindu Kush, Karakoram, Pamir and Tien Shan mountain ranges. International Centre for Integrated Mountain Development, Kathmandu

Bahr DB, Pfeffer WT, Sassolas C and Meier MF (1998) Response time of glaciers as a function of size and mass balance. 1. Theory. J. Geophys. Res., 103(B5), 9777-9782

Bolch T (2007) Climate change and glacier retreat in northern Tien Shan (Kazakhstan/Kyrgyzstan) using remote sensing data. Global Planet. Change, 56, 1-12

Bolch T and Kamp U (2006) Glacier mapping in high mountains using DEMs, Landsat and ASTER data. Grazer Schr. Geogr. Raumforsch., 41, 13-24

Bolch T and Marchenko SS (2009) Significance of glaciers, rock glaciers and ice rich permafrost in the Northern Tien Shan as water towers under climate change conditions. In Braun L, Hagg W, Severskiy I and Young G eds Assessment of snow, glacier and water resources in Asia, vol. 8. International Hydrological Programme-Hydrology and Water Resources Programme, Koblenz, 132-144

Bolch T and 7 others (2010) A glacier inventory for the western Nyainqentanglha Range and Nam Co Basin, Tibet, and glacier changes 1976-2009. Cryosphere, 4, 419-433

Braithwaite RJ and Raper SCB (2010) Estimating equilibrium-line altitude (ELA) from glacier inventory data. Ann. Glaciol., 50, $127-132$

Chaulagai N (2003) Impact of climate changes on water resources of Nepal: a case study of Tsho Rolpa glacial lake. (MSc thesis, University of Flensburg)

Cherkasov PA (2004) Raschet sostavlyauyshih vodno-ledovogo balansa vnutrikontinental'noi lednikovoi sistemy [Calculation of the components of water-ice balance of inland glacier system]. Kaganat, Almaty

Evans IS (2006) Local aspect asymmetry of mountain glaciation: a global survey of consistency of favoured directions for glacier number and altitudes. Geomorphology, 73(1-2), 166-184

Fujita K and Ageta Y (2000) Effect of summer accumulation on glacier mass balance on the Tibetan Plateau revealed by massbalance model. J. Glaciol., 46(153), 244-252

Granshaw FD and Fountain AG (2006) Glacier change (19581998 ) in the North Cascades National Park Complex, Washington, USA. J. Glaciol., 52(177), 251-256

Hagg W, Braun LN, Kuhn M, Nesgaard TI (2007) Modelling of hydrological response to climate change in glacierized Central Asian catchments. J. Hydrol., 332, 40-53

Hagg W, Mayer C, Lambrecht A, Kriegel D and Azizov E (2012) Glacier changes in the Big Naryn basin, Central Tian Shan. Global Planet. Change, 110, 40-50

Issanova G, Jilili A and Semenov O (2013) Deflation processes and their role in desertification of the southern Pre-Balkhash deserts. Arab. J. Geosci., 7(11), 4513-4521

Kaser G, Großhauser M and Marzeion B (2010) Contribution potential of glaciers to water availability in different climate regimes. Proc. Natl Acad. Sci. USA (PNAS), 107, 20 223-20 227

Katalog Lednikov SSSR [Glacier Inventory of the USSR] (1980) Centralii i luyzhnii Kazakhstan, ed. II Bassein oz. Balkhash, part 5. Bassein r. Karatala [Central and Southern Kazakhstan, ed. II Balkhash basin, part 5. Karatal river basin]. Hydrometeoizdat, Leningrad
Kokarev AL and Shesterova IN (2014) Sovremennye izmeneiya gornyh lednikov na uyzhnom sklone Dzhungarskogo Alatau [Modern change of mountain glaciers on the southern slope of the Dzhungar Alatau]. Led i Sneg, 128, 54-62

Kriegel D and 6 others (2013) Changes in glacierisation, climate and runoff in the second half of the 20th century in the Naryn basin, Central Asia. Global Planet. Change, 110, 51-61

Kudekov TK (2002) Sovremennoe ekologicheskoe sostoyanie basseina ozera Balkhash [Modern ecological condition of Balkhash Lake basin]. Kaganat, Almaty

Kutuzov S and Shahgedanova M (2009) Glacier retreat and climatic variability in the eastern Terskey-Alatoo, inner Tien Shan between the middle of the 19th century and beginning of the 21st century. Global Planet. Change, 69, 59-70

Li B, Zhu A, Zhang Y, Pei T, Qin C and Zhou C (2007) Glacier change over the past four decades in the middle Chinese Tien Shan. J. Glaciol., 52, 425-432

Li Z, Zhao Z, Edwards R, Wang W and Zhou P (2011) Characteristics of individual aerosol particles over Ürümqi Glacier No. 1 in eastern Tianshan, central Asia, China. Atmos. Res., 99, 57-66

Narama C, Shimamura Y, Nakayama D and Abdrakhmatov K (2006) Recent changes of glacier coverage in the western Terskey-Alatoo range, Kyrgyz Republic, using Corona and Landsat. Ann. Glaciol., 43, 223-229

Narama C, Kääb A, Duishonakunov M and Abdrakhmatov K (2010) Spatial variability of recent glacier area changes in the Tien Shan Mountains, Central Asia, using Corona (1970), Landsat (2000), and ALOS (2007) satellite data. Global Planet. Change, 71, $42-54$

Niederer P, Bilenko V, Ershove N, Hurni H, Yerokhin S and Maselli D (2008) Tracing glacier wastage in the Northern Tien Shan (Kyrgyzstan/Central Asia) over the last 40 years. Climatic Change, 86, 227-234

Paul F and Andreassen LM (2009) A new glacier inventory for the Svartisen region, Norway, from Landsat ETM+ data: challenges and change assessment. J. Glaciol., 55(192), 607-618 (doi: 10.3189/002214309789471003)

Paul F and Kääb A (2005) Perspectives on the production of a glacier inventory from multispectral satellite data in Arctic Canada: Cumberland Peninsula, Baffin Island. Ann. Glaciol., 42, 59-66

Paul F, Huggel C, Kääb A, Kellenberger T and Maisch M (2003) Comparison of TM-derived glacier areas with higher resolution data sets. EARSeL eProc., 2(1), 15-21

Paul F and 19 others (2013) On the accuracy of glacier outlines derived from remote-sensing data. Ann. Glaciol., 54(63 Pt 1), 171-182 (doi: 10.3189/2013AoG63A296)

Pieczonka T and Bolch T (2015) Region-wide glacier mass budgets and area changes for the Central Tien Shan between 1975 and 1999 using Hexagon KH-9 imagery. Global Planet. Change, 128, 1-13

Severskiy IV and 6 others (2012) Lednikovye sistemy BalkashAlakolskogo basseina: sostoyanie, sovremennye, izmeneniya [Glaciological system of Balkhash-Alakol basin: state and current changes]. Probl. Geogr. Geoecol., 2, 31-40

Shahgedanova M, Nosenko G, Khromova T and Muraveyev A (2010) Glacier shrinkage and climatic change in the Russian Altai from the mid-20th century: an assessment using remote sensing and PRECIS regional climate model. J. Geophys. Res., 115(D16), D16107 (doi: 10.1029/2009JD012976)

Sorg A, Bolch T, Stoffel M, Solomina O and Beniston M (2012) Climate change impacts on glaciers and runoff in Tien Shan (Central Asia). Nature Climate Change, 2, 725-731

Stocker TF and 9 others eds (2013) Climate change 2013: the physical science basis. Contribution of Working Group I to the Fifth Assessment Report of the Intergovernmental Panel on Climate Change. Cambridge University Press, Cambridge and New York 
Unger-Shayesteh K and 6 others (2013) What do we know about past changes in the water cycle of Central Asian headwaters? A review. Global Planet. Change, 110, 4-25

Vandenberghe $\mathrm{J}$ and 7 others (2006) Penetration of Atlantic westerly winds into Central and East Asia. Quat. Sci. Rev., 25, 2380-2389

Vilesov EN, Morozova VI and Severskiy IV (2013) Oledenenie Dzhungarskogo (Zhetysu) Alatau: proshloe, nastoyashee, bu dushee [Glaciation of Dzhungar (Zhetysu) Alatau: past, present, future]. Volkova, Almaty
Viviroli D, Weingartner R and Messerli B (2003) Assessing the hydrological significance of the world's mountains. Mt. Res. Dev., 23, 32-40

Wang L, Li Z, Wang F and Edwards R (2014) Glacier shrinkage in the Ebinur lake basin, Tien Shan, China, during the past 40 years. J. Glaciol., 60(220), 245-254 (doi: 10.3189/ 2014JoG13J023)

Ye B, Ding Y and Liu C (2001) Response of valley glaciers in various sizes and their runoff to climate change. J. Glaciol. Geocryol., 23(2), 103-110 